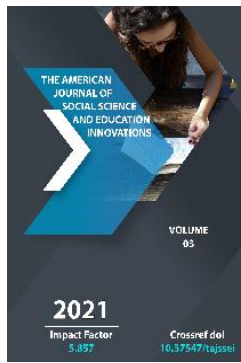

\title{
The Role And Activity Of Queens In The Education And Training Of Women Under The Temurian And Baburiyan Periods
}

\author{
Jahongir Alisherovich Safarov \\ 3 rd Year Student Faculty Of History Of Tashkent State Pedagogical University Named After \\ Nizami, Uzbekistan
}

Journal Website:

http://theamericanjour

nals.com/index.php/taj

ssei

Copyright: Original content from this work may be used under the terms of the creative commons attributes 4.0 licence.

\section{ABSTRACT}

The article discusses the emphasis on women's education during the reigns of Amir Temur and the Temurids princes, and opened up a wide range of opportunities for their education.

\section{KEYWORDS}

Amir Temur, Temurid princes, Zahiriddin Muhammad Babur, Ulugbek, women's education, renaissance.

\section{INTRODUCTION}

There is no doubt that the countries of the development of science and culture during world have a lot to say about the the Timurids and 
the emergence of a unique renaissance. Because in the Middle Ages, under the leadership of Amir Temur, a strong, centralized state was established, and the country was established by strict law and justice. Also, the spiritual and cultural heritage was restored, science flourished and the life of the country improved. During the Timurid period, the cultural treasures, spiritual heritage and values that had been trampled underfoot as a result of the Mongol invasion were restored. The activities of scientific institutions are organized and great attention is paid to the pursuit of enlightenment, the education of the perfect man. Therefore, this period has a worthy place in the history of the world and the history of our national statehood.

With the coming to power of Amir Temur in Movarounnahr, science and culture began to rise in Samarkand, Bukhara, Kashmir, Herat, India, which he conquered. Advancing in his ideas, Amir Temur did not consider the cultural life of his people as alien and made every effort for the growth of science and culture, urban economy and architecture $[3,160]$.

During the Timurid period, commendable work was done to improve the system of education and upbringing of women. During that period, women's educational endeavors were gradually supported. For example, knowledge of literature and, in particular, writing poetry in Persian was considered an attribute of women's intellectual ability. Another characteristic that distinguishes an educated woman is her ability to read verses from the Qur'an clearly and then to receive the status of "Qari-begim." Raising children in aristocratic families was a separate task entrusted to the woman as the closest profession to be performed by every woman. Women who are able to embody these three qualities in life have earned respect and esteem as educated women.

As Amir Temur tried to arouse interest in science and education in his children, the issues of education and upbringing were always in the center of his attention. He himself always showed great interest in his grandchildren, appointing guardians to them, mainly in the person of one of his wives. He showed a special love for his grandson, Ulugbek, the son of Shahrukh, who later became a great scientist-astronomer. He had appointed his eldest wife, Mrs. Saraymulk, as his guardian since childhood [2,371].

Amir Temur even took part in choosing a bride for his sons and grandsons. The future bride paid serious attention to her family, lineage and education. There are opinions that prove that Sahibkiran Amir Temur considered women and the family sacred: "I focused on looking for a bride in order to marry my sons, grandchildren and relatives. I inquired about the lineage of the bride, the seven roses. I found out about his health and physical maturity through specific people. As long as the bride is free from all defects, with her pedigree, morals, health and strength, I gave a big wedding to the people and brought the bride, "said Sahibkiran in Temur's charter. From Amir Temur onwards, the respect and honor of educated women was of special importance to all heirs and all members of the dynasty. After returning from a trip to India in 1399, Sahibkiran ordered the construction of a mosque and madrasah in honor of Bibi Khanum. Even today, this magnificent building adds splendor to Samarkand. During the reign of Amir Temur, gardens and mausoleums 
were built for other prestigious queens of the palace. The Garden of Paradise in Samarkand was built in honor of his beloved wife Tuman aga. Mirzo Ulugbek, who became a wellknown scientist and enlightener of his time, gave a special direction to the whole nation to acquire knowledge. At the request of Ulugbek, the following words were engraved on the main roof of one of the most famous madrassas in Samarkand: "It is the duty of every Muslim and Muslim woman to seek knowledge" [4,376].

She and the subsequent rulers of this dynasty created ample opportunities for education for all women who sought to understand them.

\section{MATERIALS AND METHODS}

According to sources, during the Timurids, separate schools were opened for women. Atinbibi was a teacher here. There are also schools that educate the daughters of the common people, which are organized in the neighborhoods. Specially trained horsemen taught girls in these schools. Consequently, women have often had success in learning science and especially literature. For example, the wife of the most successful 15th century poet Khoja Ismati Bukhari, who wrote under the pseudonym "Ismati", the daughter of the poet Hasan Ali Jalayr - Dilshodkhotun and his daughter Ofoqbika, the daughter of Amir Yodgor - Fakhruniso and others.

Since the Baburi dynasty did not prevent men and women from receiving education, a generation of the most literate women of the Muslim world grew up here, for example: Gulbadanbegim (Babur's daughter), Gulrukh Begim (Babur's daughter), Bakhshi Bonu Begim, (Humoyun). daughter), Salima Sultan Begim (Akbar's daughter), Nurjahon Begim
(Jahangir's wife), Jahonoro Begim (Shohjahon's daughter) and Zebunniso Begim (Avrangzeb's daughter). Each of them left a bright and unique mark and made a great contribution to the development of science, literature and art in India. For example, Bakhshi Bonu Begim was the granddaughter of Babur Mirza and the daughter of Humayun Mirza. This woman's unparalleled talent has for many years been overshadowed by littleknown historical events by members of the Baburi family. Bakhshi Bonu made a great contribution to the art of the peoples of Central Asia, laying the foundation for the folk epic "Gorogly". In his songs he sang about the events that took place during the life of the palace and the conquests, and the struggle within the seed for a useful position. The song is full of patriotism and love for the motherland. Although word of mouth has been lost in recent years and his songs have lost their original meaning, his name has gone down in history as the founder of the Gorogly epic. Salima was also a distant relative of Akbar Mirza, the son of Sultan Begim Humayun. In the future, she had managed to become Akbar Mirza's favorite wife and advisor. He also had the ability to write poetry, writing poems in Persian under the pseudonym "Secret". Many tazkirs of that period, including Saidali Hasankhan's tazkira "Subhi Gulshan", contain examples of his rubai and ghazals.

\section{RESULT AND DISCUSSION}

Another woman who wrote beautiful poems under the pseudonym "Secret" of the Baburid kingdom was Nurjahon Begim (Mehriniso), the wife of Jahangirshah (son of Akbar Mirza). He was initially educated in the family of Mirza Ghiyasbek, an Iranian intellectual. He then 
defeated Jahangir Mirza with his intelligence and talent and became not only his wife, but also the first adviser to be given the title of "King-begim". Growing up under the auspices and direct participation of her aunt, her student Mumtoz Mahal was remembered by the people as the most talented, intelligent and most beautiful queen of the Baburi dynasty. The mausoleum, built in his honor, is still one of the Seven Wonders of the World, like the Taj Mahal in India [1,169].

\section{CONCLUSION}

In short, during the reign of Amir Temur and the Temurids, a great deal of attention was paid not only to the morals of women, but also to their education. For example, the inscription on the roof of the madrasah built by Mirzo Ulugbek in Bukhara, "Education is the duty of every Muslim man and woman," in Arabic, shows the attention paid to women's education. It is not in vain that women are encouraged to acquire knowledge, because the mother's involvement in the upbringing of children is a precautionary measure to ensure that the younger generation becomes more educated and moral in the future.

\section{REFERENCES}

1. Basham A.L. The illustrated cultural history of India. Oxford university press, 2007/ - 3046.

2. Абу Бакр мухаммад ибн Джа_фар ан-Наршахи. Та'рих-и Бухара. (История Бухары). Перевод, комментарии и примечания Ш.Б. Камолиддина. Археологотопографический комментарий Е.Г. Некрасовой. - Ташкент: SMIA - SIA, 2011. - 600 б.
3. Бартольд В.В. Сочинения. Том II, часть 1. - М.: «Издательство Восточной литературы», 1963 - 1020 6.

4. История народов Узбекистана: с древнейших времен до начала XVI века. Том

5. Сиддиков, И. Б. (2019). Государственная политика в отношении молодежи в Узбекистане: национальный опыт и реальная необходимость международных инициатив. In Условия социально-экономического развития общества: история и современность (рр. 38-43). 